\title{
Helle Metslang 60
}

29. juulil 2010 sai 60-aastaseks Tartu ülikooli tänapäeva eesti keele professor Helle Metslang. Lõpetanud 1974. a Tartu ülikooli eesti filoloogina, on ta veel nende hulgas, kes võivad end pidada generatiivse grammatika grupi GGG põlvkonda kuuluvaks. Ka tema esimesed kirjutised ilmusid GGG kogumikus „Keel ja struktuur". GGG põhimõtet lähtuda eesti keele kirjeldamisel ikka uusimast teoreetilisest lingvistikast on ta järginud siiamaani.

Teadlaseks kujunes Helle Metslang siiski TA Keele ja Kirjanduse Instituudis, mille grammatikarühmas ta töötas üle kahekümne aasta. 1995. a sai temast õppejõud. 1995-2000 oli ta Helsingi ülikooli eesti keele lektor, 2004-2007 Helsingi ülikooli külalisprofessor. 2000. a valiti ta Tallinna ülikooli eesti keele professoriks ja 2001. a ka dekaaniks. 2007. a aga sai Helle Metslangist Tartu ülikooli tänapäeva eesti keele professor ja 2008. aastast alates on ta ühtlasi eesti ja üldkeeleteaduse instituudi juhataja. Nagu eesti keele professorile kohane, kuulub ta mitmetesse nõukogudesse (sh Eesti Keelenõukogusse), toimetuskolleegiumidesse, paljudesse kodu- ja välismaa teadusseltsidesse ja ühingutesse, on mitmel pool teadusekspert. Ta on Rakenduslingvistika Ühingu aastaraamatu peatoimetaja ning 2006. aastast alates Emakeele Seltsi juhatuse esimees. Muljet avaldavale ametite ja kohustuste hulgale vaatamata on ta jätkuvalt viljakas uurija.

Helle Metslangi peamisteks uurimisaladeks on olnud eesti keele morfosüntaks ja süntaks, keele muutumine, kontrastiivne ja tüpoloogiline keeleuurimine. Alustas ta aga regivärsilise rahvalaulu keele uurimisega. 1978. a kaitstud kandidaadiväitekirjas „Süntaktilisi aspekte eesti regilaulu värsiparallelismis“ vaatleb autor, kuidas luulekeelele omane paradigmaatilise ekvivalentsi kandmine süntagmaatikasse avaldub parallelismi süntaktilises struktuuris. 1970. aastate lõpp ja 1980. aastad kulusid eesti keele teaduslikku grammatikat ettevalmistavale uurimistööle ning grammatika enda koostamisele. Helle Metslang on riigi teaduspreemiaga pärjatud eesti keele teadusliku grammatika (EKG) süntaksiosa üks kahest põhiautorist. Tema koostatud on lause pragmaatilisi tähendusi, süntaktilisi protsesse, kvantorifraasi 
ning (koos Mati Ereltiga) lauseliikmeid käsitlevad osad. Suurest kollektiivtööst vabanenuna hakkas ta eesti keele ajasüsteemist doktoriväitekirja kirjutama. Artikliväitekiri "Temporal relations in the predicate and the grammatical system of Estonian and Finnish" valmis 1994. a Oulu ülikoolis ja sai seal ka edukalt kaitstud. Töö põhieesmärgiks oli anda eesti ajasüsteemi kirjeldus võrreldes soome süsteemiga, kõrvaleesmärgiks eesti ja soome keele kogu grammatilise süsteemi tüpoloogiline võrdlus. Tegemist on eriti õnnestunud uurimistööga, mida näitab see, et 1995. a anti autorile selle eest tervelt kaks suurt preemiat - Soome teadusseltside Suomalais-Ugrilainen Seura ja Kotikielen Seura väitekirjapreemia ning Eesti Vabariigi 1995. a teaduspreemia humanitaarteaduste alal.

Lisaks ajale on Helle Metslangi huvi keskmesse kuulunud ajaga tihedalt seotud aspekt, samuti kõneviisitähendused ning suhtluseesmärgid - seda nii sünkroonilisest kui ka diakroonilisest, kontrastiivsest, areaalitüpoloogilisest ja tüpoloogilisest vaatekohast. Ta on uurinud objekti käänete aspektilist iseloomu, perfektiivsuspartikli ära kujunemist ja kasutust, progressiivse mas-tarindi funktsioone ja arengut. Ta on käsitlenud kõiki kõneviise ja kõiki kommunikatiivseid lausetüüpe, viimastest eriti põhjalikult küsilauset juba 1981. a ilmunud monograafias „Küsilause eesti keeles“.

Nii väitekirja kui ka Helle Metslangi järgnenud uurimuste üheks läbivaks teemaks on olnud grammatiseerumine. Helle Metslang oli esimesi, kes hakkas eesti lingvistikas rakendama grammatiseerumise mõistet, seda nii sünkroonilises mõttes kui ka diakroonilise protsessina, olgu siis verbide (saama, hakkama jt) abiverbistumise käsitlemisel või konstruktsioonide abstraktse (grammatilise) tähenduse kujunemise kirjeldamisel. Ta on uurinud mitmete tähenduste grammatiliste väljendusvahendite kujunemist ja arengut viimase sajandi ja pikemagi perioodi jooksul.

Enamik Helle Metslangi töödest käsitleb eesti keele nähtusi võrrelduna teiste keeltega - eriti soome keelega, kuid ka mittesugulaskeeltest mõjukeelte saksa ja vene keelega ning viimasel ajal ka Euroopa keeleliidu keeltega (nn SAE-keeltega). Seejuures pole ta piirdunud üksiknähtuste võrdlemisega, vaid võrrelnud 
ka grammatilist süsteemi tervikuna. Hea ülevaate sellest annab tema kirjutis "Estonian grammar between Finnic and SAE: some comparisons" (Sprachtypologie und Universalienforschung 62 (1/2). Berlin, 2009).

Ilmselt nii keelte võrdlus kui ka pikaajaline pedagoogitöö Helsingi ülikoolis on sundinud Helle Metslangi tegelema eesti keele piirkondadega, mis valmistavad raskusi muulasest keeleõppijale, samuti keele keerukuse kui teoreetilise probleemiga. Tema juhtimisel on koostatud Euroopa Liidu Phare eesti keele õppe projekti raames keelekäsiraamat „Keelehärm: eesti keele probleemseid piirkondi““ (Tallinna Pedagoogikaülikool, 2003), milles tema enda koostatud on lauseõpetuse osa.

Helle Metslang kuulub nende eesti keele uurijate hulka, kes on pidanud väga oluliseks rahvusvahelist suhtlust ning eesti keele uurimise tulemuste avaldamist peale Eesti ka välismaal. Ta kuulub rahvusvahelistesse lingvistikaühingutesse Association of Linguistic Typology, Societas Linguistica Europea, International Pragmatic Association ning Soome ühingutesse SuomalaisUgrilainen Seura ja Suomen Kielitieteellinen Yhdistys. Ta on avaldanud kirjutisi mainekates rahvusvahelistes ajakirjades, esinenud ettekannetega paljudel rahvusvahelistel konverentsidel ning loengutega peale Soome ka Saksamaa, Venemaa, Itaalia ja Ungari ülikoolides.

Helle Metslang on olnud viljakas ja innovaatiline uurija, tuntud ja hinnatud mitte ainult Eestis ja Soomes, vaid mujalgi. Tartu ja Tallinna ülikooli professorina on tal olnud ka rohkesti õpilasi, kellest kaks on jõudnud ja hea mitu peatselt jõudmas doktorikraadini. Tal on tulnud täita arvukalt teadusorganisatoorseid kohustusi, millega tal on hoolimata oma leebest loomust õnnestunud suurepäraselt toime tulla. Soovime talle uurimis-, õpetamis- ja korraldamisindu ka tulevikuks!

Kolleegide nimel Mati Erelt 